\title{
Polyhydroxybutyrate production in Bacillus mycoides DFC1 using response surface optimization for physico-chemical process parameters
}

\author{
Aarthi Narayanan · Karna Venkata Ramana
}

Received: 17 December 2011/Accepted: 5 March 2012/Published online: 23 March 2012

(C) The Author(s) 2012. This article is published with open access at Springerlink.com

\begin{abstract}
The production of polyhydroxybutyrate (PHB) by Bacillus sp. is most often growth associated and is influenced by various physico-chemical parameters. Imbalanced nutrient conditions were often found to result in sporulation and low PHB production in Bacillus sp. In the present investigation, Bacillus mycoides DFC1 strain isolated from garden soil was studied for PHB production in glucose-peptone broth. The effect of glucose/peptone ratio on biomass yield, PHB production and sporulation was investigated. Central composite rotatable design was used to study the interactive effects of three variables: glucose, peptone and $\mathrm{pH}$ on cell growth and PHB production. The optimized medium conditions with the constraint 'to maximize' cell growth and PHB content were glucose $17.34 \mathrm{~g} / \mathrm{l}$, peptone $7.03 \mathrm{~g} / \mathrm{l}$ at pH 7.3. A maximum dry cell weight of $4.35 \mathrm{~g} / \mathrm{l}$ and PHB yield of $3.32 \mathrm{~g} / \mathrm{l}$ amounting to $76.32 \%(w / w)$ of dry cell weight with negligible sporulation at the end of $72 \mathrm{~h}$ resulted in a significant increase $(1.83-3.32 \mathrm{~g} / \mathrm{l}$ or 1.82 -fold) in the production of PHB in comparison to the medium used in preliminary studies.
\end{abstract}

Keywords Bacillus mycoides - Glucose/peptone ratio . Nutrient limitation $\cdot$ Sporulation $\cdot$ Statistical design

\section{Introduction}

Polyhydroxyalkanoates (PHAs) are biodegradable polyesters produced by bacteria which are gaining importance as alternative biopolymers to petroleum-based plastics due to their eco-friendly nature. Bacteria of different genera accumulate

A. Narayanan · K. V. Ramana ( $₫)$

Food Biotechnology Division, Defence Food Research

Laboratory, Siddharthanagar, Mysore 570011, Karnataka, India

e-mail: ecobiotech2020@gmail.com
PHAs as intracellular carbon and energy storage granules in response to growth media containing excess carbon substrate and limited quantities of nitrogen source (Anderson and Dawes 1990). They are readily degraded by the depolymerases present in the environmental microflora resulting in the formation of water and $\mathrm{CO}_{2}$ (Suriyamongkol et al. 2007). Several Gram positive and Gram negative bacteria are widely known to produce PHAs, however, only Gram negative bacteria have been extensively studied. Bacteria such as Ralstonia eutropha (Cupriavidis necator), Alcaligenes latus and other methylotrophs accumulate PHA when cell growth is hampered due to the limitation of nitrogen/phosphorous/ magnesium/potassium/oxygen or sulphur in the presence of excess carbon source (Doi 1990). The members of the genus Bacillus are reported to accumulate PHB during the growth phase (Borah et al. 2002). PHAs can be subdivided into three broad classes according to the size of monomers. PHAs containing up to C5 monomers are classified as short chain length PHAs (scl-PHA), whereas PHAs containing carbon chain length in the range of $\mathrm{C} 6-\mathrm{C} 14$ and $>\mathrm{C} 14$ monomers are classified as medium chain length (mcl-PHA) and long chain length (lcl-PHA) PHAs, respectively (Rehm 2003). In comparison to other PHAs, polyhydroxybutyrate (PHB) is too brittle to be used as plastic material. Members of Pseudomonas sp., Aeromonas hydrophila as well as Bacillus sp. are reported to accumulate heteropolymers of short chain lengthmedium chain length PHAs (scl-mcl PHA) such as $\mathrm{P}$ (3HB-co$3 \mathrm{HV}), \mathrm{P}(3 \mathrm{HB}-\mathrm{co}-3 \mathrm{HHx})$ and $\mathrm{P}(3 \mathrm{HB}-\mathrm{co}-4 \mathrm{HB})$ when substrates such as $\gamma$-butyrolactone or $\varepsilon$-caprolactone are present in the growth medium as carbon source (Labuzeck and Radecka 2001). Unlike the Gram negative bacteria the polymer produced by Bacillus sp. are free from endotoxins and can be used for biomedical applications. These tailor-made biosynthesized polymers are considered to exhibit better physical properties and can find use as biodegradable food packaging 
materials, adhesives as well as biocompatible materials for tissue engineering applications. B. circulans, B. licheniformis, B. amyloliquefaciens, B. thuringiensis, B. cereus UW85, B. megaterium Y6, B. sphaericus ATCC 14577, B. coagulans and $B$. mycoides RLJB-017 were reported to produce PHAs in the range 11-69\%w/w of dry cell weight (Chen et al. 1991; Borah et al. 2002; Katricioglu et al. 2003; Yilmaz et al. 2005; Singh et al. 2009). Our experimental studies identified $B$. mycoides DFC1 also to accumulate poly (3HB-co-3HV) copolymer with high hydroxyvalerate (-HV) content of $31.3 \mathrm{~mol} \%$ (unpublished results). Although PHB was first identified in Bacillus sp, until now the large-scale PHB production using Bacillus sp. has been met with limited success (Wu et al. 2001; Valappil et al. 2007). Bacillus sp. strains endowed with rapid growth and ability to utilize a variety of readily available cost-effective substrates is neglected due to the sporulation interfering with $\mathrm{PHB}$ production (Wu et al. 2001). Few studies have documented the accumulation of PHB in Bacillus sp. during the late log phase or early stationary phase; however, the accumulated PHB was found to be degraded at the onset of sporulation (Chen et al. 1991; McCool et al. 1996). An optimized medium might enhance and maintain PHA content even at the instance of sporulation in Bacillus sp. The parameters such as the carbon (C) and nitrogen $(\mathrm{N})$ source as well as $\mathrm{pH}$ of the medium exert an influence on the metabolism of these bacteria and accumulation of PHB (Wu et al. 2001). Response surface methodology (RSM) is an efficient tool used to study the interactive effect of parameters involved in fermentation process seeking optimized conditions for improved product yields (Montgomery 2005; Pal et al. 2010). In the present study Bacillus mycoides DFC1, a growth-associated PHB-producing bacteria was grown under conditions favoring $\mathrm{PHB}$ production and was investigated for sporulation. Initial $\mathrm{pH}$ of the medium and the glucose/peptone $(G / P)$ ratio was found to support the stable PHB production without reduction in PHB biosynthesis. Few reports on the optimization of PHB production from Bacillus sp. has been documented (Valappil et al. 2007; Pandian et al. 2010); however, detailed studies on the correlation of the medium composition and its $\mathrm{pH}$ favoring $\mathrm{PHB}$ production over sporulation are lacking. The aim of the present study is to optimize $\mathrm{PHB}$ production and control the sporulation in B. mycoides DFC1 for the enhanced PHB production through statistical media optimization for its possible application in scale-up studies.

\section{Materials and methods}

\section{Microorganism}

The PHB-producing bacterium used in the present study was isolated from garden soil at Mysore, India. The strain was identified by sequencing the $1.4 \mathrm{~kb}$ of $16 \mathrm{~S}$ rRNA gene amplified using universal forward primer: $5^{\prime}$ AGAGTTTGATCCTGGCTAG $3^{\prime}$ and reverse primer: $5^{\prime}$ AAGGAGGTGATCCAGCC $3^{\prime}$. The $16 \mathrm{~S}$ rRNA gene sequence analysis was carried out using NCBI-BLAST homology search (National centre for Biotechnology Information http://www.ncbi.nml.nih.gov) program and identified the bacterium as Bacillus mycoides DFC1. The nucleotide sequence have been deposited with NCBI database under the accession number GQ344802 (Aarthi and Ramana 2011). The glycerol stock culture maintained at $4{ }^{\circ} \mathrm{C}$ was used for inoculum preparation.

Comparison of PHB production in different media

Three different media were investigated to determine the suitable composition supporting maximum PHB accumulation by $B$. mycoides DFC1. The media reported earlier by Ramsay et al. (1990) and Tajima et al. (2003), respectively, were compared with modified glucose-peptone broth whose composition comprise/l: $10.0 \mathrm{~g}$ glucose, $5.0 \mathrm{~g}$ peptone and $5.0 \mathrm{~g}$ sodium chloride for PHB production. Three percent $(\mathrm{v} / \mathrm{v})$ of the $18 \mathrm{~h}$ culture was used as inoculum in all experiments. The flasks were incubated at $37^{\circ} \mathrm{C}$ at $140 \mathrm{rpm}$ for $48 \mathrm{~h}$. The sporulation in the fermentation media at the end of $48 \mathrm{~h}$ was determined as the number of heat-stable cells present after heat treatment at $80{ }^{\circ} \mathrm{C}$ for 20 min according to Stevenson and Segner (2001).

\section{Effect of culture conditions on PHB production}

Based on the results from preliminary experiments, the glucose-peptone broth (GPB) was used further to identify the appropriate glucose/peptone $(G / P)$ ratio for PHB production. The initial concentration of glucose was varied from 5.0 to $20.0 \mathrm{~g} / \mathrm{l}$ and the $G / P$ ratio of the medium was further adjusted to $1.5-15.0$ by varying the concentration of peptone for $15.0 \mathrm{~g} / \mathrm{l}$ of glucose. The residual glucose was estimated by 3,5-dinitrosalicylic acid method (Somogyi 1952). Based on the preliminary 'one-factor-at-a-time' optimization method, the medium containing $3: 1(G / P)$ ratio with an initial $\mathrm{pH} 7.3$ resulted in a maximum $\mathrm{PHB}$ production. This data was further used to fit in the design of experiments for response surface optimization.

Experimental design and optimization

The optimization of process parameters in growth-associated PHB production by $B$. mycoides DFC1 was studied using central composite rotatable design (CCRD) of RSM (StatEase, Inc Design Expert software, trial version, 8.03, Minneapolis, USA). The CCRD for the three independent variables: glucose $(A, \mathrm{~g} / \mathrm{l})$, peptone $(B, \mathrm{~g} / \mathrm{l})$ and $\mathrm{pH}(C)$ each 
at five levels including 6 replicates at the center point, 6 axial points $(\alpha= \pm 1.682)$ and 8 factor points leading to a total number of 20 experiments was employed for optimization. Each variable was studied at two different levels $(-1,+1)$ and center point $(0)$ which is the midpoint of each factor range. Table 3 shows the minimum and maximum range of variables investigated and the full experimental plan with respect to their actual and coded values. The experimental results were fitted with a second-order polynomial function:

$$
\begin{aligned}
Y= & b_{0}+b_{1} x_{1}+b_{2} x_{2}+b_{3} x_{3}+b_{11} x_{1}^{2}+b_{22} x_{2}^{2} \\
& +b_{33} x_{3}^{2}+b_{12} x_{1} x_{2}+b_{13} x_{1} x_{3}+b_{23} x_{2} x_{3}
\end{aligned}
$$

where, $Y$ is the predicted response, $b_{0}$ the intercept, $b_{1}, b_{2}$, $b_{3}$ the linear coefficient, $b_{11}, b_{22}, b_{33}$ the squared coefficient and $b_{12}, b_{13}, b_{23}$ the interaction coefficient.

Data analysis

Design Expert 8.03 (Stat-Ease, Inc, Minneapolis, USA) was used for the data analysis. The response surface model graphs were used to identify the effects of linear, quadratic and interactive terms of the independent variables on the chosen dependent variables. To validate the model, the average of each response (cell dry weight and PHB content) was determined from the completely optimized medium composition in duplicates. The statistical significance of the model was checked by Fischer's $F$ test and the level of significance was given as $p$ value.

\section{Extraction and characterization of PHB}

The biomass was separated by centrifugation at $9,000 \times g$ for $10 \mathrm{~min}$ and washed twice with double distilled water. The biomass was kept in $-20{ }^{\circ} \mathrm{C}$ overnight and later freeze dried under vacuum for $5 \mathrm{~h}$ using Heto Dry winner model DW3 lyophilizer. The cell dry weight (cdw) measured in grams per liter $(\mathrm{g} / \mathrm{l})$ of culture broth was determined from the lyophilized biomass. The PHB extraction was carried out by dissolving dried biomass preparations in equal volume of sodium hypochlorite $(\mathrm{pH}$ 12.0) and chloroform and incubating the mixture at $37{ }^{\circ} \mathrm{C}$ for $1 \mathrm{~h}$. The mixture was filtered and the PHB content defined as the ratio of PHB concentration to cell concentration was quantified from the chloroform phase by gravimetric method (Hahn et al. 1995). The residual biomass or non-PHB content was determined as the difference between the cell concentration and PHB. The polymer samples were analyzed for its purity using Thermo-Nicolet FT-IR spectrometer, Model 5700, (Madison WI). The spectra were recorded in the MID IR range from 4,000 to $650 \mathrm{~cm}^{-1}$, using single bounce attenuated total reflectance (ATR) accessory with zinc selenide crystal. Sixty-four scans were averaged to get the spectra. The IR spectra were recorded with $4 \mathrm{~cm}^{-1}$ resolution and analysis of the spectra was carried out using OMNIC software.

\section{Results and discussion}

Identification of a suitable media for PHB production

The yields of biomass and PHB as well as the percentage of sporulation in three different media are shown in Fig. 1. B. mycoides DFC1 showed less growth and PHB production in Basal mineral salt medium (BMSLM). The endospore staining revealed $>60 \%$ sporulation under nutrient-limited conditions when compared with the other two media. Chen et al. (1991) earlier reported on the degradation of the PHB polymer due to sporulation while Fujita et al. (2005) discussed on the regulation of the gene SpoOA responsible for sporulation during nutrient limitation. The present data also corroborated the interference of PHB production by sporulation in B. mycoides DFC1 due to nutrient limitation in
Fig. 1 Comparison of cell growth, sporulation and PHB production by $B$. mycoides DFC1 in different media

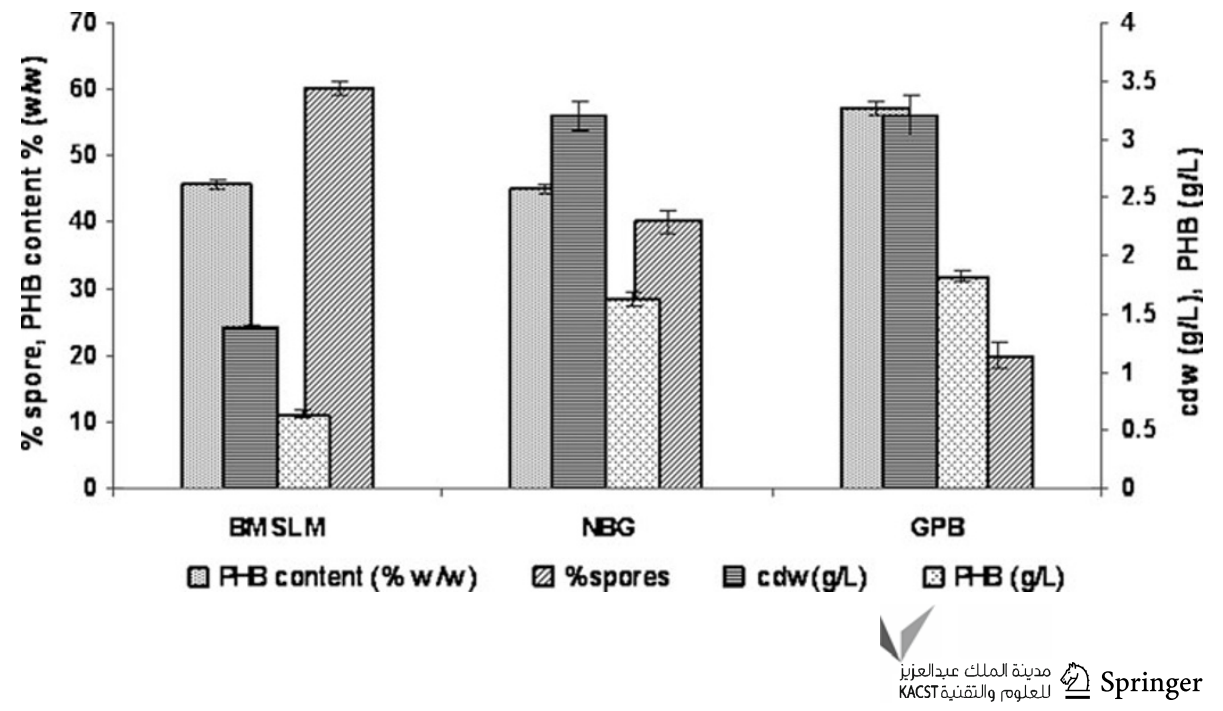


BMSLM. Further, the PHB production in GPB medium $(1.83 \mathrm{~g} / \mathrm{l})$ was equally effective as nutrient broth medium with $1.0 \%$ glucose (NBG medium) of Tajima et al. (2003), $(1.62 \mathrm{~g} / \mathrm{l})$, indicating that a high PHB accumulation $(57.2 \% \mathrm{w} / \mathrm{w})$ in the isolated strain, B. mycoides DFC1 could be achieved with these media ingredients.

Determination of initial glucose concentration

The concentration of the glucose in the culture medium determines the cell growth and PHB production. The results for the initial glucose concentration of the GPB medium supporting maximum PHB production is shown in Fig. 2. It is evident that both cell growth and PHB content improved as the initial concentration of glucose was increased from 5.0 to $20.0 \mathrm{~g} / \mathrm{l}$. Maximum cell growth and glucose utilization occurred up to $15.0 \mathrm{~g} / \mathrm{l}$, as a result the medium became acidic ( $\mathrm{pH}$ 5.2). Fluorescence microscopic study after every $12 \mathrm{~h}$ revealed that the low $\mathrm{pH}$ of the medium did not affect the PHB accumulation and resulted in $65.22 \% \mathrm{w} / \mathrm{w}$ of dry cell weight at the end of $72 \mathrm{~h}$.

\section{Effect of $G / P$ ratio and initial $\mathrm{pH}$}

In the present study the $G / P$ ratio was identified to affect the growth-associated PHB production as well as sporulation to a certain extent in B. mycoides DFC1. Table 1 show that the 3:1 G/P ratio supported maximum biomass and PHB content. Studies on the use of protein hydrolysates and other organic nitrogen sources to support good biomass and PHB content has been reported for bacteria such as $R$. eutropha, Azotobacter beijerinckii and recombinant E. coli (Lee and Chang 1994; Bormann et al. 1998a, b). The extremes of $G / P$ ratio, i.e. the presence of excess peptone or glucose does not favor for a high PHB content. The use of $\mathrm{C} / \mathrm{N}$ ratio as an important parameter in fermentation process to achieve high cell density and product formation was documented by Grothe et al. (1999). Similarly, a high $\mathrm{C} / \mathrm{N}$ ratio favoring maximum PHB accumulation in Alcaligenes eutrophus has been reported by Park et al. (1997).

The spores were not detected in the production media until $72 \mathrm{~h}$ with $<80$ spores $/ \mathrm{ml}$ present at the end of $120 \mathrm{~h}$. The reason for such delayed sporulation could be due to the presence of peptone as the complex nutrient which probably regulates the flux of metabolic intermediates towards PHB biosynthesis favoring growth-associated PHB production in B. mycoides. Earlier studies also documented on the stimulation of spore formation in response to stringent conditions (De Vries et al. 2004).

The effect of initial $\mathrm{pH}$ was investigated for the $3: 1 \mathrm{G} /$ $P$ ratio and the results are shown in Table 2. Although cell growth and PHB production was observed from $\mathrm{pH} 5.7$ onwards, the PHB content $(11.3 \pm 0.5 \% \mathrm{w} / \mathrm{w})$ was low at the end of $48 \mathrm{~h}$. The maximum PHB accumulation $(65.5 \pm 1.5 \% \mathrm{w} / \mathrm{w})$ was observed at $\mathrm{pH} 7.3$ with minimum sporulation and remained stable without undergoing degradation. Bacillus sp. strains are known to produce several metabolic intermediates such as acetate, lactate and acetoin
Fig. 2 Effect of initial glucose production in GPB media concentration on $\mathrm{PHB}$

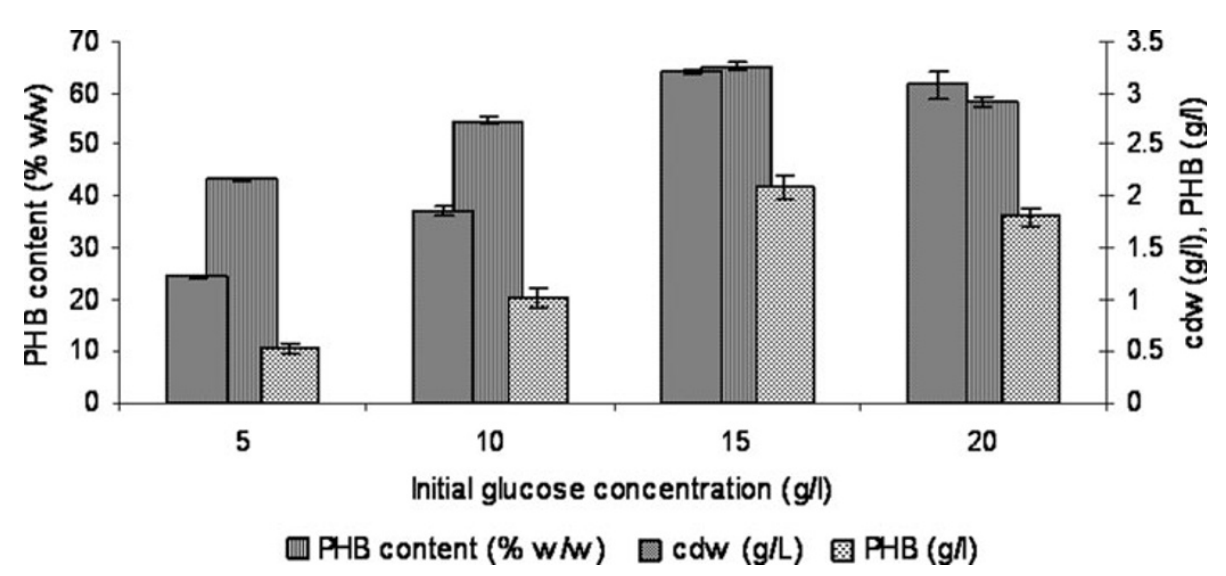

Table 1 Effect of $G / P$ ratio on PHB production

\footnotetext{
${ }^{\text {a }}$ Mean \pm SD of triplicate experiments
}

\begin{tabular}{lllll}
\hline Parameters & \multicolumn{3}{l}{$G / P$ ratio } & \\
\cline { 2 - 5 } & $15: 1$ & $5: 1$ & $3: 1$ & 1.5 \\
\hline Dry cell weight $(\mathrm{g} / \mathrm{l})$ & $0.76 \pm 0.01$ & $2.12 \pm 0.2$ & $3.20 \pm 0.1$ & $3.4 \pm 0.1$ \\
PHB content $(\% \mathrm{w} / \mathrm{w})$ & $43.4 \pm 0.3$ & $50.3 \pm 0.3$ & $59.5 \pm 0.2$ & $30.4 \pm 0.5$ \\
Spores/ml $^{\mathrm{a}}$ & $2.6 \times 10^{6}$ & $2.1 \times 10^{3}$ & $0.73 \times 10^{2}$ & $3.4 \times 10^{4}$ \\
Residual glucose $(\mathrm{g} / \mathrm{l})$ & $4.8 \pm 0.2$ & $4.1 \pm 0.3$ & $3.2 \pm 0.1$ & $3.5 \pm 0.3$ \\
Final $\mathrm{pH}$ & $4.5 \pm 0.01$ & $5.1 \pm 0.01$ & $5.3 \pm 0.02$ & $4.9 \pm 0.01$ \\
\hline
\end{tabular}


during growth and the accumulated PHB is used as energy source at the time of sporulation (Benoit et al. 1990). In the present study, the PHB remained stable probably due to

Table 2 Effect of initial $\mathrm{pH}$ on PHB production and sporulation

\begin{tabular}{lllr}
\hline Initial $\mathrm{pH}$ & $\mathrm{Cdw}(\mathrm{g} / \mathrm{l})$ & PHB $(\% \mathrm{w} / \mathrm{w})$ & \multicolumn{1}{c}{ Spores $/ \mathrm{ml}^{\mathrm{a}}$} \\
\hline 5.7 & $0.24 \pm 0.07$ & $11.3 \pm 0.5$ & $6.3 \times 10^{4}$ \\
5.9 & $0.49 \pm 0.05$ & $16.3 \pm 0.1$ & $5.7 \times 10^{4}$ \\
6.1 & $0.66 \pm 0.03$ & $32.3 \pm 0.5$ & $5.5 \times 10^{3}$ \\
6.3 & $0.74 \pm 0.03$ & $38.3 \pm 1.1$ & $4.4 \times 10^{2}$ \\
6.5 & $0.93 \pm 0.05$ & $42.6 \pm 0.1$ & $3.1 \times 10^{2}$ \\
6.7 & $1.62 \pm 0.06$ & $52.4 \pm 0.6$ & $2.3 \times 10^{2}$ \\
6.9 & $1.86 \pm 0.13$ & $57.3 \pm 0.5$ & $1.3 \times 10^{2}$ \\
7.1 & $2.11 \pm 0.07$ & $60.2 \pm 1.3$ & $1 \times 10^{2}$ \\
7.3 & $2.23 \pm 0.12$ & $65.5 \pm 1.5$ & $0.4 \times 10^{2}$ \\
7.5 & $3.12 \pm 0.16$ & $63.7 \pm 1.1$ & $0.87 \times 10^{2}$ \\
\hline
\end{tabular}

Mean \pm SD of triplicate experiments

a Average of triplicate experiments some factors suppressing the intermediates of sporulation, further confirming importance of this process parameter in the production medium.

\section{Characterization of $\mathrm{PHB}$}

The FT-IR spectroscopy of the extracted polymer showed an intense band at $1,720 \mathrm{~cm}^{-1}$ corresponding to the estercarbonyl $(\mathrm{C}=\mathrm{O})$ stretching vibration (data not shown) characteristic for the short chain length monomers of PHB (Hong et al. 1999).

\section{Statistical optimization of PHB production}

Based on the results of the preliminary experiments, CCRD was used to determine the optimized culture conditions to maximize cell growth and PHB production using GPB media. The experimental design matrix is presented in Table 3 and the data obtained were used to develop models through the second-order polynomial model equation
Table 3 Experimental design matrix in terms of actual, coded factors and the observed values for the responses-cell dry weight (cdw) and PHB content

\begin{tabular}{|c|c|c|c|c|c|c|}
\hline \multirow[t]{2}{*}{ Variables } & \multirow[t]{2}{*}{ Symbol } & \multicolumn{5}{|l|}{ Coded levels } \\
\hline & & -1.68 & Low $(-1)$ & Mid (0) & High (1) & +1.68 \\
\hline Glucose $(\mathrm{g} / \mathrm{l})$ & $A$ & 2.39 & 7.50 & 15.00 & 22.50 & 27.61 \\
\hline Peptone (g/l) & $B$ & 0.80 & 2.50 & 5.00 & 7.50 & 9.20 \\
\hline $\mathrm{pH}$ & $C$ & 6.80 & 7.00 & 7.30 & 7.60 & 7.80 \\
\hline \multirow[t]{2}{*}{ Run order } & \multirow[t]{2}{*}{ Factor A } & \multirow[t]{2}{*}{ Factor B } & \multirow[t]{2}{*}{ Factor $\mathrm{C}$} & \multicolumn{3}{|c|}{ Mean observed response } \\
\hline & & & & $\begin{array}{l}\text { Cell dry } \\
\text { weight } \\
\left(Y_{1}\right) \mathrm{g} / 1\end{array}$ & $\begin{array}{l}\text { PHB content } \\
\left(Y_{2}\right)(\% \mathrm{w} / \mathrm{w})\end{array}$ & \\
\hline 1 & $15.00(0)$ & $5.00(0)$ & $7.30(0)$ & 4.22 & 70.3 & \\
\hline 2 & $15.00(0)$ & $5.00(0)$ & $7.30(0)$ & 4.32 & 74.2 & \\
\hline 3 & $2.39(-1.682)$ & $5.00(0)$ & $7.30(0)$ & 1.21 & 34.5 & \\
\hline 4 & $22.50(1)$ & $2.50(-1)$ & $7.60(1)$ & 0.70 & 21.5 & \\
\hline 5 & $7.50(-1)$ & $2.50(-1)$ & $7.60(1)$ & 1.45 & 52.7 & \\
\hline 6 & $27.61(+1.682)$ & $5.00(0)$ & $7.30(0)$ & 1.67 & 33.5 & \\
\hline 7 & $7.50(-1)$ & $2.50(-1)$ & $7.00(-1)$ & 2.24 & 59.4 & \\
\hline 8 & $15.00(0)$ & $5.00(0)$ & $7.30(0)$ & 4.15 & 74.4 & \\
\hline 9 & $22.50(1)$ & $2.50(-1)$ & $7.00(-1)$ & 0.82 & 25.3 & \\
\hline 10 & $7.50(-1)$ & $7.50(1)$ & $7.00(-1)$ & 2.32 & 38.7 & \\
\hline 11 & $15.00(0)$ & $9.20(+1.682)$ & $7.30(0)$ & 4.18 & 69.4 & \\
\hline 12 & $15.00(0)$ & $5.00(0)$ & $7.80(+1.682)$ & 3.24 & 65.2 & \\
\hline 13 & $7.50(-1)$ & $7.50(1)$ & $7.60(1)$ & 2.45 & 34.6 & \\
\hline 14 & $22.50(1)$ & $7.50(1)$ & $7.00(-1)$ & 3.13 & 67.4 & \\
\hline 15 & $15.00(0)$ & $0.80(-1.68)$ & $7.30(0)$ & 1.15 & 31.3 & \\
\hline 16 & $22.50(1)$ & $7.50(1)$ & $7.60(1)$ & 3.52 & 61.7 & \\
\hline 17 & $15.00(0)$ & $5.00(0)$ & $7.30(0)$ & 3.87 & 72.8 & \\
\hline 18 & $15.00(0)$ & $5.00(0)$ & $7.30(0)$ & 4.17 & 73.3 & \\
\hline 19 & $15.00(0)$ & $5.00(0)$ & $7.30(0)$ & 3.92 & 74.4 & \\
\hline 20 & $15.00(0)$ & $5.00(0)$ & $6.80(-1.682)$ & 3.11 & 72.5 & \\
\hline
\end{tabular}


(Eqs. 2, 3) which allows all the linear and quadratic components of the main effects and the linear-by-linear interactions to be estimated.

$$
\begin{aligned}
\text { Cell dry weight }(\mathrm{g} / \mathrm{l})\left(Y_{1}\right)= & +4.15+0.035 A+0.88 B \\
& -0.013 C+0.51 A B+0.12 A C \\
& +0.18 B C-1.02 A^{2}-0.51 B^{2} \\
& -0.41 C^{2} \quad\left(R^{2}=0.97\right)
\end{aligned}
$$

PHB content $(\% \mathrm{w} / \mathrm{w})\left(Y_{2}\right)=+73.71-0.82 A+7.88 B$

$$
\begin{aligned}
& -2.39 C+15.14 A B+0.16 A C \\
& +0.088 B C-14.95 A^{2}-9.17 B^{2} \\
& -2.63 C^{2} \quad\left(R^{2}=0.97\right)
\end{aligned}
$$

The analysis of variance (Tables 4,5 ) indicated that $B$, $A B, A^{2}, B^{2}$ and $C^{2}$ as significant terms $(p<0.05)$ for cell growth and PHB content. The sign and magnitude of the coefficients indicated the effect of the variables on the responses. At quadratic level glucose $(A)$ and $\mathrm{pH}(C)$ were found to have significant $(p<0.05)$ negative effect on both cell growth and PHB content and therefore can act as limiting factor at high concentrations leading to sporulation. Glucose and peptone $(B)$ showed significant $(p<0.05)$ positive interactive effect for both cell growth and PHB content. In Fig. 3a-d are shown the surface plots for the interactive factors glucose, peptone and $\mathrm{pH}$. The $2 \mathrm{D}$ contour and the 3D response surface plots are generally the graphical representation of the regression equation and the
Table 4 Analysis of regression coefficients and their significance for the responsecell dry weight $\left(Y_{1}\right)$

$S S$ sum of squares, $d f$ degrees of freedom, $M S$ mean square,

$R^{2} \%=97.2$

\# Lack of fit is not significant

${ }^{a}$ Significant at $p$ value $<0.05$

Table 5 Analysis of regression coefficients and their significance for the responsePHB content $\left(Y_{2}\right)$

$S S$ sum of squares, $d f$ degrees of freedom, $M S$ mean square, $R^{2} \%=97.0$

\# Lack of fit is not significant

${ }^{a}$ Significant at $p$ value $<0.05$

\begin{tabular}{lllllrl}
\hline Term & \multicolumn{6}{l}{ Cell dry weight $\left(Y_{1}\right)$} \\
\cline { 2 - 7 } & Regression & SS & $d f$ & MS & $F$ value & $p$ value Prob $>F$ \\
\hline Intercept & 4.15 & 31.65 & 9 & 3.52 & 39.57 & $0.0001^{\mathrm{a}}$ \\
Glucose $(A)$ & 0.035 & 0.017 & 1 & 0.017 & 0.19 & 0.6700 \\
Peptone $(B)$ & 0.88 & 10.60 & 1 & 10.60 & 119.24 & $0.0001^{\mathrm{a}}$ \\
$\mathrm{pH}(C)$ & -0.013 & $2.150 \mathrm{E}-003$ & 1 & $2.150 \mathrm{E}-003$ & 0.024 & 0.8765 \\
$A B$ & 0.51 & 2.05 & 1 & 2.05 & 23.07 & $0.0001^{\mathrm{a}}$ \\
$A C$ & 0.12 & 0.11 & 1 & 0.11 & 1.22 & 0.2958 \\
$B C$ & 0.18 & 0.26 & 1 & 0.26 & 2.88 & 0.1207 \\
$A^{2}$ & -1.02 & 15.07 & 1 & 15.07 & 169.63 & $0.0001^{\mathrm{a}}$ \\
$B^{2}$ & -0.51 & 3.80 & 1 & 3.80 & 42.78 & $0.0001^{\mathrm{a}}$ \\
$C^{2}$ & -0.41 & 2.41 & 1 & 2.41 & 27.17 & $0.0004^{\mathrm{a}}$ \\
Residual & - & 0.89 & 10 & 0.089 & & \\
Lack of fit & - & 0.68 & 5 & 0.14 & 3.33 & $0.1602^{\#}$ \\
Pure error & - & 0.21 & 5 & 0.041 & & \\
Total & - & 32.53 & 19 & & &
\end{tabular}

\begin{tabular}{lcrrrrl}
\hline Term & Regression & \multicolumn{2}{l}{ PHB content $\left(Y_{2}\right)$} & & \\
\cline { 2 - 7 } & & \multicolumn{1}{c}{ SS } & $d f$ & \multicolumn{1}{c}{ MS } & $F$ value & $p$ value Prob $>F$ \\
\hline Intercept & 73.71 & $6,849.16$ & 9 & 761.02 & 36.80 & $0.0001^{\mathrm{a}}$ \\
Glucose $(A)$ & -0.82 & 9.16 & 1 & 9.16 & 0.44 & 0.5209 \\
Peptone $(B)$ & 7.88 & 847.39 & 1 & 847.39 & 40.97 & $0.0001^{\mathrm{a}}$ \\
pH $(C)$ & -2.39 & 77.71 & 1 & 77.71 & 3.76 & 0.0813 \\
$A B$ & 15.14 & $1,833.15$ & 1 & $1,833.15$ & 88.64 & $0.0001^{\mathrm{a}}$ \\
$A C$ & 0.16 & 3.65 & 1 & 3.65 & 0.76 & 0.4045 \\
$B C$ & 0.088 & 1.81 & 1 & 1.81 & 0.38 & 0.5539 \\
$A^{2}$ & -14.95 & $3,219.60$ & 1 & $3,219.60$ & 155.68 & $0.0001^{\mathrm{a}}$ \\
$B^{2}$ & -9.17 & $1,210.83$ & 1 & $1,210.83$ & 58.55 & $0.0001^{\mathrm{a}}$ \\
$C^{2}$ & -2.63 & 55.67 & 1 & 55.67 & 11.57 & $0.0068^{\mathrm{a}}$ \\
Residual & - & 206.81 & 10 & 20.68 & & \\
Lack of fit & - & 35.66 & 5 & 7.13 & 2.86 & $0.1365^{\#}$ \\
Pure Error & - & 20.45 & 5 & 4.09 & & \\
Total & - & $7,055.97$ & 19 & & & \\
\hline
\end{tabular}




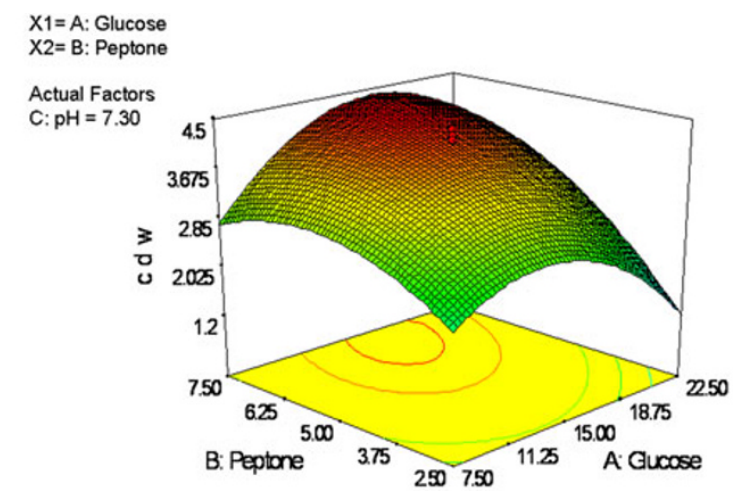

a

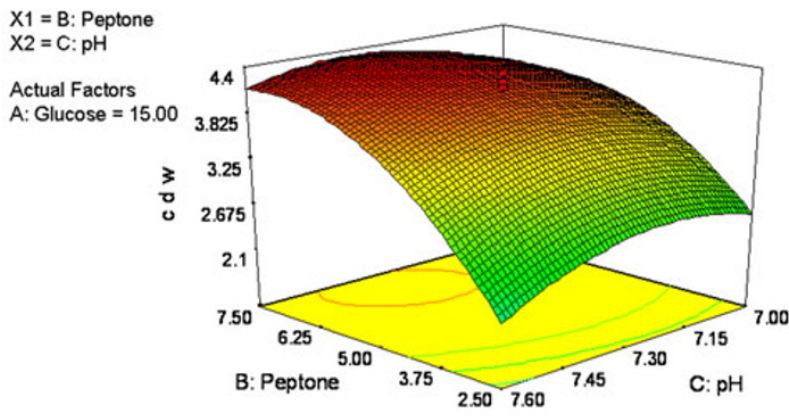

C

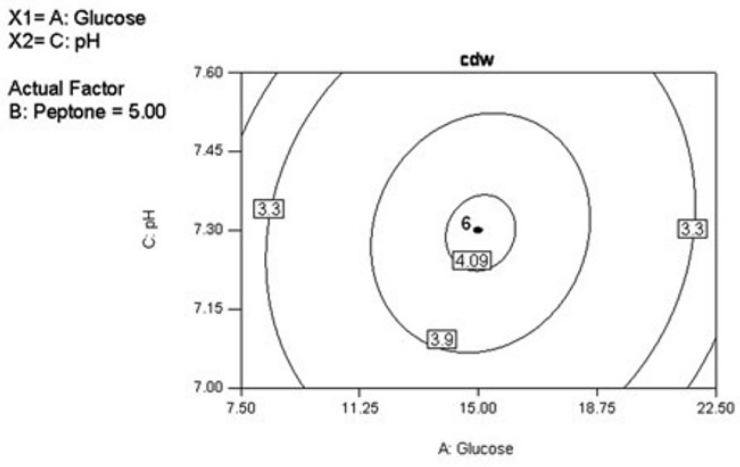

e

Fig. 3 a-d Surface plots showing the interactive effect of glucose versus peptone for the responses: a cell dry weight $(\mathrm{g} / \mathrm{l})$ and $\mathbf{b}$ PHB content $(\% \mathrm{w} / \mathrm{w})$; interactive effect shown as a function of peptone

interaction between the variables can be inferred from the shapes of the surface plots (Yu et al. 2008). The maximum predicted cell dry weight $(4.45 \mathrm{~g} / \mathrm{l})$ and PHB content $(75.92 \% \mathrm{w} / \mathrm{w})$ increased with increase in the concentration of peptone. Further, the interaction between glucose and $\mathrm{pH}$ was negligible and observed as circular plots (Fig. 3e, f) when peptone concentration was kept constant at $5.0 \mathrm{~g} / \mathrm{l}$. The results indicate that the responses varied much as function of concentration of peptone and it is essential to maintain a proper $G / P$ ratio in growthassociated PHB-producing bacteria to achieve maximum PHB production. Similar studies on the importance of the

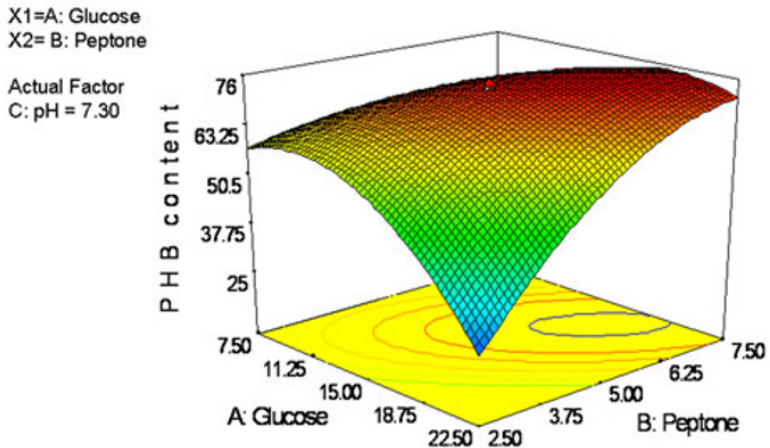

b
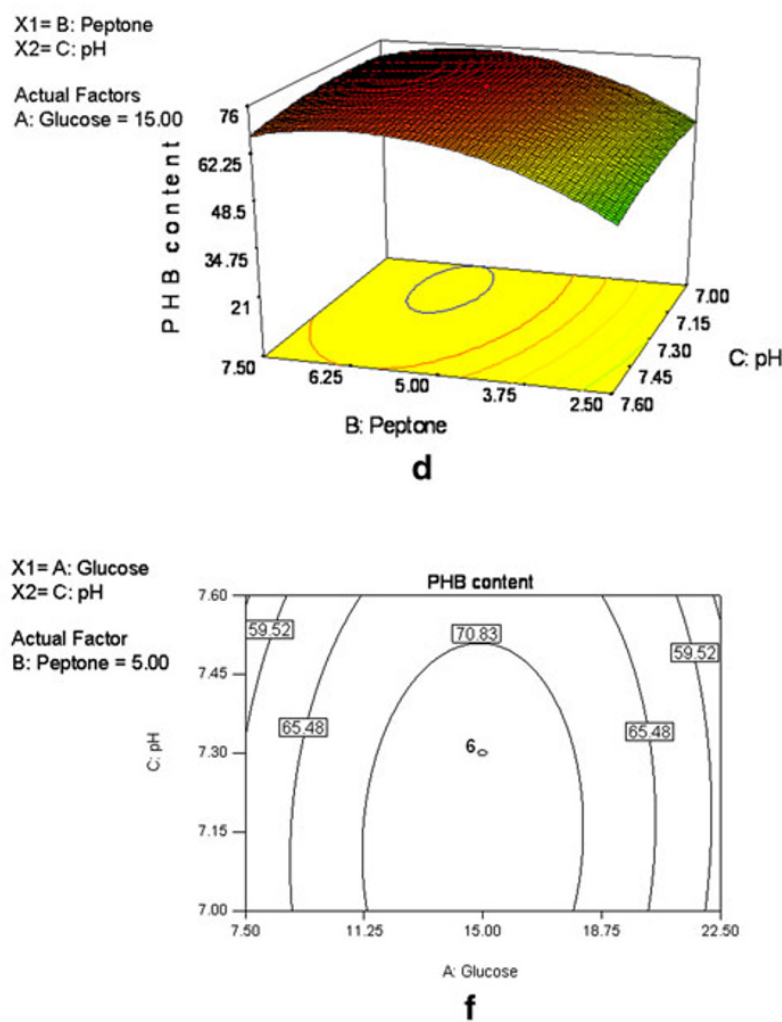

versus $\mathrm{pH}$ for cell dry weight and $\mathbf{d}$ PHB content. e-f Interactive effect shown as a function of glucose versus $\mathrm{pH}$ for the responses e cell dry weight and $\mathbf{f}$ PHB content

presence of complex organic nutrients favoring PHB production has been reported for some bacteria such as Azotobacter vinelandii (Page et al. 1992) and recombinant E. coli (Song et al. 1999).

The significance and adequacy of the model was assessed using $F$ test and determination coefficient $\left(R^{2}\right)$ of the analysis of variance (ANOVA). The model $F$ value for the responses cell dry weight and PHB content were high, i.e., 39.57 and 36.80 , respectively. A high model $F$ value indicates the model as significant and the factors could explain adequately the variation in the data around its mean. The goodness of fit of the model determined by 
correlation coefficient was also high $\left(R^{2}=0.97\right)$ for both the responses, since $R^{2}>0.75$ indicates aptness of the model. The adequate precision value which measures the signal-to-noise ratio is 16.135 and 16.445 for cell growth and PHB content. A value of $>4$ is considered desirable and indicate that the model could navigate the design space which is further corroborated by the insignificant lack of fit values (Tables 4,5 ).

Model validation and PHB production

The recommended solution obtained for the constraint to 'maximize' cell dry weight and PHB content was glucose $17.34 \mathrm{~g} / \mathrm{l}$, peptone $7.03 \mathrm{~g} / \mathrm{l}$ and $\mathrm{pH}$ 7.3. With the optimized solution, experiments were carried out in duplicates to evaluate the accuracy of the predicted model using the modified GPB medium. The percentages of relative deviation for the validated responses calculated for the predicted and observed response are shown in Table 6. Further the time course fermentation study (Fig. 4) revealed that the PHB content $(76.32 \% \mathrm{w} / \mathrm{w})$ showed a 1.82 -fold increase (1.82-3.32 g/l) after optimization using response surface methodology in comparison to the media used in the preliminary studies. The endospore staining and fluorescence microscopic studies of bacterial cells revealed negligible ( $\sim 40$ spores $/ \mathrm{ml})$ spore count for the optimized media at the end of $72 \mathrm{~h}$ which further substantiate the efficiency of the GPB media for PHB production. The yield obtained is comparatively higher when compared with other Bacillus sp. strains like Bacillus sp INT005 (35.30\%) (Tajima et al. 2003), Bacillus cereus SPV (38.0\%) (Valappil et al. 2007), Bacillus cereus CFR06 (46.0 \%) (Halami 2008) reported so far. Although Bacillus sp. are considered as industrial workhorses for the production of various enzymes, antibiotics and host for recombinant DNA technology after E. coli, the studies on industrial scale PHB production has not drawn much attention due to the limitations of PHB as energy source for sporulation process (Singh et al. 2009; Jendrossek 2009). The present study identified a production medium with minimum ingredients for PHB biosynthesis by B. mycoides $\mathrm{DFC1}$, which resisted sporulation for longer hours (72 $\mathrm{h})$ as

Table 6 Constraints, criteria for optimization, solution along with predicted and observed response values

\begin{tabular}{llccccccc}
\hline Name & Goal & $\begin{array}{l}\text { Lower } \\
\text { limit }\end{array}$ & $\begin{array}{l}\text { Upper } \\
\text { limit }\end{array}$ & Importance & Solution & $\begin{array}{l}\text { Observed } \\
\text { response }\end{array}$ & $\begin{array}{l}\text { Predicted } \\
\text { response }\end{array}$ & $\begin{array}{l}\text { Relative } \\
\text { deviation }(\%)^{\mathrm{a}}\end{array}$ \\
\hline Glucose $(\mathrm{g} / \mathrm{l})$ & Is in range & 7.5 & 22.5 & 3 & 17.34 & - & - & - \\
Peptone $(\mathrm{g} / \mathrm{l})$ & Is in range & 2.5 & 7.5 & 3 & 7.03 & - & - & - \\
Initial pH & Target $=7.30$ & 7.0 & 7.6 & 3 & 7.30 & - & - & - \\
Cdw $(\mathrm{g} / \mathrm{l})$ & Maximize & 0.7 & 4.61 & 4 & 4.20 & 4.35 & 4.50 & 3.33 \\
PHB content $(\% \mathrm{w} / \mathrm{w})$ & Maximize & 15.7 & 74.4 & 5 & 75.7 & 76.32 & 75.7 & -0.92 \\
\hline
\end{tabular}

${ }^{a}$ Relative deviation $=\frac{\text { Predicted response-observed response } \times 100}{\text { Predicted response }}$

b Average of duplicate experiments

Fig. 4 Time course study of biomass and PHB production in optimized media by $B$. mycoides DFC1

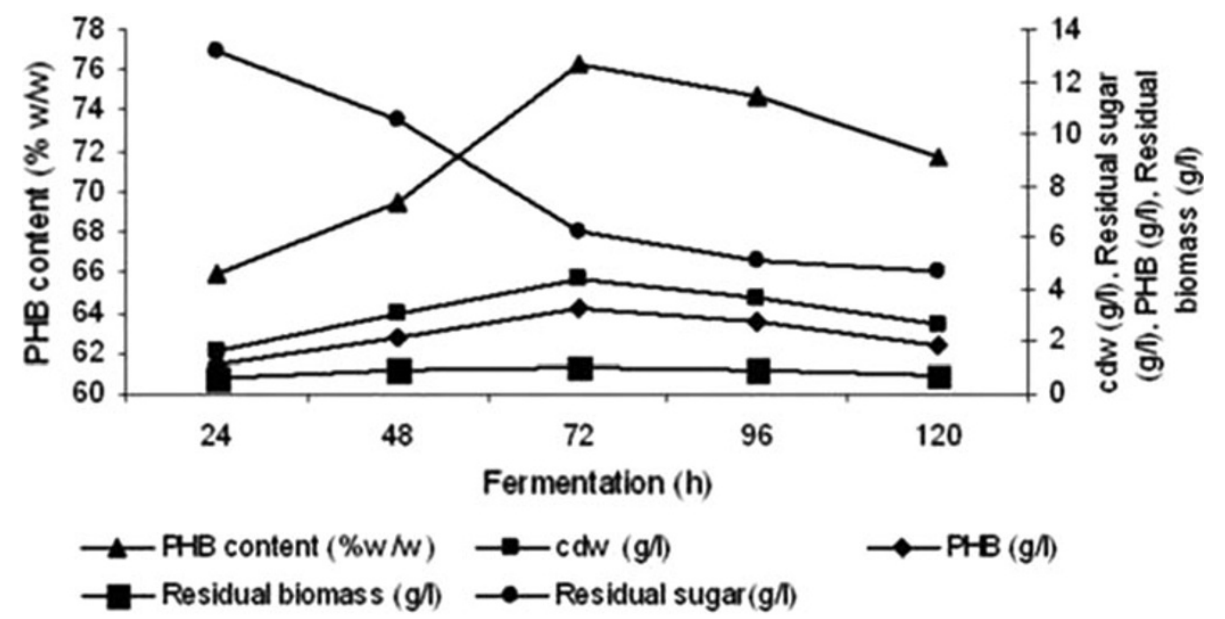

Residual biomass $=$ Non PHB content biomass;

$\mathrm{PHB}$ content $=\mathrm{PHB}$ concentration-cell concentration/cell concentration $\times 100$ 
well as accumulated PHB to the maximum extent of $\sim 76.0 \%$ of its dry cell weight when compared to earlier reports.

\section{Conclusion}

In the present investigation, the conditions favoring maximum PHB production over sporulation was evaluated using a modified glucose-peptone medium by one-factorat-a-time approach. The application of statistical optimization helped to determine collectively the optimum process conditions responsible for PHB production. The study also revealed that selected process parameters supported maximum PHB accumulation and also reduced the problem of sporulation. Further scale-up studies using the optimized media by $B$. mycoides DFC1 is under progress.

Acknowledgments The authors are grateful to Dr. A.S. Bawa, Director, Defence Food Research Laboratory, Mysore, for providing constant guidance and encouragement.

Open Access This article is distributed under the terms of the Creative Commons Attribution License which permits any use, distribution, and reproduction in any medium, provided the original author(s) and the source are credited.

\section{References}

Aarthi N, Ramana KV (2011) Identification and characterization of polyhydroxybutyrate producing Bacillus cereus and Bacillus mycoides strains. Int J Environ Sci 1:744-756

Anderson AJ, Dawes EA (1990) Occurrence, metabolism, metabolic role and industrial uses of bacterial polyhydroxyalkanoates. Microbiol Rev 54:450-472

Benoit TG, Wilson GR, Baugh CL (1990) Fermentation during growth and sporulation of Bacillus thuringiensis HD-1. Lett Appl Microbiol 10:15-18. doi:10.1111/j.1472-765X.1990. tb00084.x

Borah B, Thakur PS, Nigam JN (2002) The influence of nutritional and environmental conditions on the accumulation of poly- $\beta$ hydroxybutyrate in Bacillus mycoides RLJ B017. J Appl Microbiol 92:776-783. doi:10.1046/j.1365-2672.2002.01590.x

Bormann EJ, Leibner M, Beer B (1998a) Growth associated production of poly (hydroxybutyric acid) by Azotobacter beijerinckii from organic nitrogen substrates. Appl Microbiol Biotechnol 49:84-88. doi:10.1007/s002530051141

Bormann EJ, Leibner M, Roth M, Beer B, Metzner K (1998b) Production of polyhydroxybutyrate by Ralstonia eutropha from protein hydrolysates. Appl Microbiol Biotechnol 50:604-607. doi:10.1007/s002530051342

Chen GQ, Koenig KH, Lafferty RM (1991) Occurrence of polyhydroxyalkanoates in the genus Bacillus. FEMS Microbiol Lett 84:173-176

De Vries YP, Hornstra LM, De Vos WM, Abee T (2004) Growth and sporulation of Bacillus cereus ATCC 14579 under defined conditions: temporal expression of genes for key sigma factors. Appl Environ Microbiol 70:2514-2519. doi:10.1128/AEM.70.4. 2514-2519.2004
Doi Y (1990) Microbial polyesters. Wiley-VHC, New York

Fujita M, Gonzalez-Pastor JE, Losick R (2005) High- and lowthreshold genes in the Spo0A regulon of Bacillus subtilis. J Bacteriol 187:1357-1368. doi:10.1128/JB.187.4.13571368.2005

Grothe E, Moo-Young M, Chisti Y (1999) Fermentation optimization for the production of poly ( $\beta$-hydroxybutyric acid) microbial thermoplastic. Enz Microb Technol 25:132-141. doi:10.1016/S01410229(99)00023-X

Hahn SK, Chang YK, Lee SY (1995) Recovery and characterization of poly (3-hydroxybutyric acid) synthesized in Alcaligenes eutrophus and recombinant Escherichia coli. Appl Environ Microbiol 61:34-39

Halami PM (2008) Production of polyhydroxyalkanoate from starch by the native isolate Bacillus cereus CFR06. World J Microbiol Biotechnol 24:805-812. doi:10.1007/s11274-007-9543-Z

Hong K, Sun SQ, Tian WD, Chen GQ (1999) A rapid method for detecting bacterial PHA in intact cells by FTIR. Appl Microbiol Biotechnol 51:523-526. doi:10.1007/s002530051427

Jendrossek D (2009) Polyhydroxyalkanoate granules are complex subcellular organelles (carbonosomes). J Bacteriol 191:3195-3202. doi:10.1128/JB.01723-08

Katricioglu H, Aslim B, Yuksekdao ZN, Mercan N, Beyatli Y (2003) Production of poly- $\beta$-hydroxybutyrate (PHB) and differentiation of putative Bacillus mutant strains by SDS-PAGE of total cell protein. Afr J Biotechnol 2:147-149

Labuzeck S, Radecka I (2001) Biosynthesis of tercopolymer by Bacillus cereus UW85. J Appl Microbiol 90:353-357

Lee SY, Chang HN (1994) Effect of complex nitrogen source on the synthesis and accumulation of poly (3-hydroxybutyric acid) by recombinant Escherichia coli in flask and fed-batch cultures. J Polym Environ (previously J Environ Polym Degrad) 2:169-176. doi:10.1007/BF02067442

McCool GJ, Fernandez T, Li N, Cannon MC (1996) Polyhydroxyalkanoate inclusion-body growth and proliferation in Bacillus megaterium. FEMS Microbiol Lett 137:41-48

Montgomery DC (2005) Design and analysis of experiments, 6th edn. Wiley, New York

Page WJ, Manchack J, Rudy B (1992) Formation of poly(hydroxybutyrate-co-hydroxyvalerate) by Azotobacter vinelandii UWD. Appl Environ Microbiol 58:2866-2873

Pal A, Ramana KV, Bawa AS (2010) Simplification and optimization of deMan Rogosa Sharpe (MRS) medium for enhanced production of bacteriocin by Weissella paramesenteroides DFR-8. J Food Sci Technol 47:254-261. doi:10.1007/s13197-010-0040-2

Pandian SR, Deepak V, Kalishwaralal K, Rameshkumar N, Jeyaraj M, Gurunathan S (2010) Optimization and fedbatch production of PHB utilizing dairy waste and seawater as nutrient sources by Bacillus megaterium SRKP-3. Bioresour Technol 101:705-711. doi:10.1016/j.biortech.2009.08.040

Park JS, Huh TL, Lee YH (1997) Characteristics of cell growth and poly- $\beta$-hydroxybutyrate biosynthesis of Alcaligenes eutrophus transformants harboring cloned phbCAB genes. Enz Microb Technol 21:85-90. doi:10.1016/S0141-0229(96)00237-2

Ramsay BA, Lomalizza K, Chavarie C, Dube B, Batallie P, Ramsay JA (1990) Production of poly-( $\beta$-hydroxybutyric-co- $\beta$-hydroxyvaleric acids). Appl Environ Microbiol 56:2093-2098 (PMCID: PMC184565)

Rehm BHA (2003) Polyester synthases: natural catalysts for plastics. Biochem J 376:15-33. doi:10.1042/BJ20031254

Singh M, Patel SKS, Kalia VC (2009) Bacillus subtilis as potential producer for polyhydroxyalkanoates. Microb Cell Fact 8:38. doi: $10.1186 / 1475-2859-8-38$

Somogyi M (1952) Note on sugar determination. J Biol Chem 195:19-25

Song S, Hein S, Steinbuchel A (1999) Production of poly (4hydroxybutyric acid) by fed-batch cultures of recombinant 
strains of Escherichia coli. Biotechnol Lett 21:193-197. doi: 10.1023/A: 1005451810844

Stevenson KE, Segner WP (2001) Mesophilic aerobic spore formers. In: Downes FP, Ito K (eds) Compendium of methods for the microbiological examination of foods, 4th edn. American Public Health Association, Washington, DC, pp 223-227

Suriyamongkol P, Weselake R, Naraine S, Moloney M, Shah S (2007) Biotechnological approaches for the production of polyhydroxyalkanoates in microorganisms and plants-a review. Biotechnol Adv 25:148-175. doi:10.1016/j.biotechadv.2006.11.007

Tajima K, Igari T, Nishimura D, Satoh Y, Munekata M (2003) Isolation and characterization of Bacillus sp. INT005 accumulating polyhydroxyalkanoate (PHA) from gas field soil. J Biosci Bioeng 95:77-81

Valappil SP, Misra SK, Boccaccini AR, Keshavarz T, Bucke C, Roy I (2007) Large-scale production and efficient recovery of PHB with desirable material properties, from the newly characterized Bacillus cereus SPV. J Biotechnol 132:251-258. doi:10.1016/j. jbiotec.2007.03.013

Wu Q, Huang H, Hu G, Chen J, Ho KP, Chen GQ (2001) Production of poly-3-hydroxybutyrate by Bacillus sp. JMa5 cultivated in molasses media. Antonie van Leewenhoek 80:111-118. doi: 10.1023/A:1012222625201

Yilmaz M, Soran H, Beyatli Y (2005) Determination of poly- $\beta$ hydroxybutyrate (PHB) production by some Bacillus sp. World J Microbiol Biotechnol 21:565-566. doi:10.1007/s11274004-3274-1

Yu L, Lei T, Rena X, Pei X, Feng Y (2008) Response surface optimization of 1-(+)-lactic acid production using corn steep liquor as an alternative nitrogen source by Lactobacillus rhamnosus CGMCC 1466. Biochem Eng J 39:496-502 (http://dx.doi.org/ 10.1016/j.bej.2007.11.008) 